would appear to be consistent with those obtained with rats (Gladfelter \& Brobeck, 1962).

Interestingly, Zeigler (1963) produced locomotor activity reductions with lesions in the dorsal forebrain, the hyperstriatum, whereas basal forebrain lesions were employed in the present study. Neural fibers have been shown to leave the accessory hyperstriatum and dorsomedial hemisphere, combining to form part of the descending septomesencephalic tract in the avian forebra in (Adamo, 1967 ; Ariens-Kappers, Huber, \& Crosby, 1967). Portions of this tract pass to the paleostriatum, preoptic, and anterolateral hypothalamic areas. As well, there is a variety of ventral forebrain fiber groupings connecting telecephalic (e.g., parolfactory lobe, paleostriatum) and diencephalic (e.g., thalamus, hypothalamus) structures (Ariens-Kappers, Huber, \& Crosby, 1967). Perhaps such forebrain fibers of passage and/or termination, relating dorsal and ventral forebrain areas, were destroyed in the present study, thus possibly disrupting a functional neural circuit between these two areas.

The present study identifies only a part of the neural network involved in the control of locomotor activity, a system which may be critical for such behaviors as exploration and defense or in the control of the arousal under different levels of external stimulation. Further neuroanatomical and behavioral study is required to establish the basal and other forebrain structures which control the responsiveness of avians to their environment.

\section{REFERENCES}

ADAMO, N. J. Connections of efferent fibers from hyperstriatal areas in chicken, raven, and African love-bird. Journal of Comparative Neurology, 1967, 131, 337-355.

AKERMAN, B., FABRICIUS, E., LARSSON, B., \& STEEN, L Observations on pigeons (Columba livia) with prethalamic radiolesions in the nervous pathways from the telecephalon Acta Physiologica Scandinavia, 1962,56, 286-298.

ANAND, B. K., \& DUA, S. Feeding responses induced by electrical stimulation of the hypothalamus in the cat. Indian Journal of Medical Research, $1955,43,113$.

ARIENS-KAPPERS, C. U., HUBER, G. C., \& CROSBY, E. C. The comparative anatomy of the nervous system of vertebrates, including man, New York: Hafner, 1967.

BROBECK, J. R. Regulation of feeding and drinking. In $\mathrm{N} W$. Magoun and V. E. Hall (Eds.), Handbook of physiology. Baltimore: Williams \& Wilkins, 1960. Pp. 1197-1206.

FELDMAN, S. E., LARSSON, S., DIMICK, M. K.. \& LEPKOVSKY. S. Aphagia in Physiology, 1957, 191, 259-261.

GLADFELTER. W. E., \& BROBECK, J. R. Decreased spontaneous locomotor activity in the rat induced by hypothalamic lesions. American Journa of Physiology, 1962, 203, 811-817.
HETHERINGTON. A. W.. \& RANSON, S W. The spontaneous activity and food intake of rats with hypothalamic lesions. American Journal of Physiology, 1942, $136,609-617$.

KARTEN, H. J., \& HODOS, W. A stereotaxic atlas of the brain of the pigeon. Baltimore: Johns Hopkins Press, 1967.

ROGERS, F. T. Studies of the brain stem. VI. An experimental study of the corpus striatum of the pigeon as related to various instinctive types of behavior. Journal of Comparative Neurology, 1922 , 35, 21-59.
TUGE, H., \& SHIMA, I. Defensive conditioned reflex after destruction of the forebrain in pigeons. Journal of Comparative Neurology, 1959, 111 , 21-59.

WOLFE, L, F., \& YEN, J. S. Improved staining of unembedded brain tissue. Physiology \& Behavior, 1968, 3, 209-210. ZEIGLER, H. P. Effects of forebrain lesions upon activity in pigeons. Journal of Comparative Neurology, 1963, 120, 183-194.

ZEIGLER, H. P., GREEN, H. L., \& KARTEN, H. J. Neural control of feeding behavior in the pigeon. Psychonomic Science, $1969,15,156-157$.

\title{
The effect of prior housing on adrenal response to isolation grouping in male albino mice*
}

\author{
PAUL F. BRAIN $†$ and NORMAN W. NOWELL \\ Department of Zoology, The University of Hull, Yorkshire, England
}

An investigation was carried out to determine if immediately prior housing conditions had any effect on the subsequent adrenal response to isolation grouping in young albino male mice. It was found that previous isolation appeared to accentuate the response to pairing and that the decline in relative adrenal weight following isolation of initially paired mice was not so marked.

It has been previously shown that Tuck albino TT strain mice which are isolated differ from grouped animals with respect to a number of behavioral and physiological parameters. The single female has a heavier adrenal, a lower "basal" level of plasma corticosterone, a heavier ovary and hemiuterus, and is more likely to be in estrus than its grouped counterpart (Brain \& Nowell, 1970c). The isolated male, on the other hand, has a lighter adrenal, lower plasma levels ot corticosterone (both "basal" and "stressed"), a heavier ventral prostate (indicative of increased androgen production), and is more aggressive than its grouped counterpart (Brain \& Nowell, 1969b, 1970b). In a study on the effects of differential grouping on mature males of this strain, these results were confirmed, but it was also found that paired mice exhibited a somewhat greater response to grouping in terms of increased adrenal weight, elevated levels of "basal" plasma corticosterone, and depressed ventral prostate weight than did some larger groups (Brain \& Nowell, 1970a).

Many studies have been carried out on the effects of grouping on adrenal weights of male mice, often with conflicting results (e.g., Christian, 1955a, b; Southwick \& Bland, 1959; Vandenberg, 1960; Welch \& Klopfer, 1961; Thiessen et al, 1962; Bronson \&

*Supported by a S.R.C. grant.

+Present address: Department of Zoology, University of Sheffield, Yorkshire, England.
Eleftheriou, 1963; Thiessen, 1964; Bailey, 1966; Essman, 1966; Sigg et al, 1966; Louch \& Higginbotham, 1967; Anton, 1969; Archer, 1969a, b). These experiments often differed with regard to the initial housing of the animals immediately prior to separation into experimental categories of different density. There are two likely explanations for the difference in adrenal function between isolated and grouped male mice. The classical one is that of Christian et al (1965), stating that the increasing density to which animals in larger groups are submitted leads to an increase in adrenocortical activity and to a depression in gonadal function. Another interpretation is the reverse of this argument, namely, that a decline in density leads to the activation of the pituitary-gonadal function, which, in the case of the male, results in an androgen mediated depression in adrenal size and function (androgens are known to depress adrenal weight). It was thought to be pertinent to attempt to determine if either of these two interpretations was true, and an experiment was devised in which both the initial and the subsequent housing of young male mice were varied and the consequent effects of these treatments on adrenal weight were described.

\section{METHODS}

Young male mice of the albino TT strain (originally obtained from A. Tuck \& Sons, Ltd., Essex) utilized in this study were from breeding cycles which are described in more 
Table 1

$\mathrm{N}=\mathbf{2 0}$

\begin{tabular}{|c|c|c|c|c|}
\hline Category & $\begin{array}{c}\text { Mean } \\
\text { Body } \\
\text { Weight (g) }\end{array}$ & $\begin{array}{c}\text { Mean } \\
\text { Relative } \\
\text { Weight Left } \\
\text { Adrenal } \\
(\mathrm{mg} / 100 \mathrm{~g})\end{array}$ & $\begin{array}{c}\text { Mean Relative } \\
\text { Weight } \\
\text { Ventral } \\
\text { Prostate } \\
\text { (mg/100g) }\end{array}$ & $\begin{array}{c}\text { Mean } \\
\text { Relative } \\
\text { Weight } \\
\text { Preputial } \\
\text { (mg/100g) }\end{array}$ \\
\hline $\begin{array}{l}\text { Isolated } \\
\text { Throughout }\end{array}$ & $40.82 \pm 0.65$ & $6.08 \pm 0.21$ & $32.75 \pm 7.1$ & $130.3 \pm 7.1$ \\
\hline $\begin{array}{l}\text { Isolated } \\
\text { Then Paired }\end{array}$ & $38.69 \pm 1.00$ & $7.66 \pm 0.39$ & $30.73 \pm 1.38$ & $127.5 \pm 7.2$ \\
\hline $\begin{array}{l}\text { Paired } \\
\text { Throughout }\end{array}$ & $40.41 \pm 1.25$ & $6.61 \pm 0.36$ & $33.11 \pm 1.52$ & $113.7 \pm 7.4$ \\
\hline $\begin{array}{l}\text { Paired } \\
\text { Then Singled }\end{array}$ & $39.83 \pm 0.90$ & $5.79 \pm 0.21$ & $32.46 \pm 1.86$ & $129.3 \pm 8.1$ \\
\hline
\end{tabular}

detail elsewhere (Brain \& Nowell, 1969a). Briefly, the mice were kept in conditions entailing minimal extraneous stress, with a light regimen of $12 \mathrm{~h}(08: 00-20: 00 \mathrm{~h})$. They were obtained from litters born within a 5 -day period which had been culled on the day of birth to six and had then remained unhandled until weaning at 18-22 days of age, when they were segregated into single-sex groups of six. The animals were used at 30 days of age, 40 males being housed singly in opaque plastic cages measuring $30.5 \times 12.75 \times 12.75 \mathrm{~cm}$ and 40 males being housed in pairs in similar cages. After 3 weeks of this differential housing, 20 of the single mice were paired and 20 of the paired mice were isolated, resulting in four categories of treatment of 20 mice each. These categories were maintained for a further 3 weeks; the mice were then sacrificed by cervical dislocation, and weights of body, left adrenal, ventral prostate, and the (squeezed) preputial gland were obtained.

RESULTS AND DISCUSSION

Table 1 lists the mean values for body weights, relative left adrenal gland weights, relative ventral prostate weights, and relative preputial weights for the four experimental categories

There were no significant differences between the four categories as regards body, relative ventral prostate, or relative preputial gland weights. Isolating a mouse and then grouping it resulted in the highest relative adrenal weight and the converse (grouping then isolating) the lowest. There was a significant difference on the student $t$ test between the relative adrenal weights of animals that had been isolated throughout the experimental period and animals that had been isolated before being grouped for a 3-week period $(t=3.623, \quad p<.001)$. The difference in adrenal weight between the mouse that had been singled and then paired and the mouse that had been paired and then singled also reached significance $(t=4.343$, $\mathrm{p}<.001$ ).
The results are in accord with previous findings that a difference exists between adrenal function of isolated and grouped males of this strain. It also appears that high adrenal weights in male mice are induced by the effects of social stress in groups and that a period of prior isolation intensifies this effect, probably by rendering the animals more aggressive and, consequently, encouraging fighting behavior following subsequent grouping. Although singling paired males resulted in a decline in adrenal weight, this fall was not significant, and it seems that the isolation effect on adrenal weight is, at best, slower in its action than the effects of grouping, given a history of isolation. There is also some indication that continuous grouping is less stressful than grouping following isolation, and this result could be regarded as indicative of "social inertia" in stable groups. As previous work has indicated that, in the case of the male, relative adrenal weight is a good indication of adrenal function in terms of plasma levels of corticosterone (Brain \& Nowell, $1970 \mathrm{a}, \mathrm{b})$, it seems likely that the adrenal changes described here are a reasonable index of social stress.

The lack of significant changes in the weights of the prostate and preputial glands is surprising in the light of the well-documented differences in weights of these organs in isolated as compared with grouped males, but it could be that both the relatively short period of isolation grouping and the smallness of the "group" were factors which prevented the normal differential from appearing.

The results, as a whole, are of importance to the design of experiments purporting to demonstrate the effects of "crowding" on rodent species.

\section{REFERENCES}

ANTON, A. H. Effects of group size, sex, and time on organ weights, catecholamines, and behavior in mice. Physiology \& Behavior, 1969, 4, 483-487.
ARCHER, J. Effects of social stimuli on the adrenal cortex in male mice. Psychonomic Science, 1969a, 14, 17-18

ARCHER, J. Chronic effects of social stimuli on adrenocortical function in male mice. Psychonomic Science, $1969 \mathrm{~b}$, $16,23-24$

BAILEY, E. D. Social interaction as a population regulating mechan is $m$ in mice. Canadian Journal of Zoology, 1966, 44 1007-1012.

BRAIN, P. F., \& NOWELL, N. W. Some behavioral and endocrine relationships in adult male laboratory mice subjected to open tield and aggression tests. Physiology \& Behavior, 1969a, 4 945-947.

BRAIN, P. F., \& NOWELL, N. W. The effects of isolation as opposed to grouping on adrenal and gonadal function in male and female mice. Journal of Endocrinology, $1969 \mathrm{~b}, 46$, xvi-xvii.

BRAIN, P. F., \& NOWELL, N. W. the effects of differential grouping on endocrine function of mature male albino mice. Physiology \& Behavior, 1970a, 5. 907-910.

BRAIN, P, F., \& NOWELL, N. W. Isolation versus grouping effects on adrenal and gonadal function in albino mice. 1 . The male. General \& Comparative Endocrinology, $1970 \mathrm{~b}$.

BRAIN, Y. F., \& NOWELL, N. W. Isolation versus grouping effects on adrenal and gonadal function in albino mice. II. The female. General \& Comparative Endocrinology, $1970 \mathrm{c}$.

BRONSON, F.H., \& ELEFTHERIOU, B. E. Adrenal responses to crowding in Peromyscus and C57BL/10J mice. Physiological Zoology, 1963, 36, 161-166.

CHRISTIAN, J. J. Effects of population size on the weights of the reproductive organs of white mice. American Journal of Physiology, 1955a, 181, 477-480.

CHRISTIAN, J, J. Effect of population size on the adrenal glands and reproductive organs of male mice in populations of fixed size. American Journal of Physiology, 1955b, 182, 292-300.

CHRISTIAN, J. J LLOYD, J A., \& DAVIS. D. E. The role of endocrines in the self-regulation of mammalian populations. Recent Progress in Hormone Research, 1965, 21,501-578.

ESSMAN, W, B. Gastric ulceration as a function of food deprivation in isolated vs aggregated mice. Psychonomic Science, $1966,4,251-252$.

LOUCH,$C$ D. \& HIGGINBOTHAM, M. The relationship between social rank and plasma corticosterone levels in mice. General \& Comparative Endocrinology, $1967,8,441.444$.

SIGG, E. B., DAY, C., \& COLOMBO, C Endocrine factors in isolation-induced aggressiveness in rodents. Endocrinology, $1966,78,679-684$

SOUTHWICK, C. H., \& BLAND, V. P. Effects of population density on adrenal glands and reproductive organs of $\mathrm{CFW}$ mice. American Joumal of Physiology, $1959,197,111-114$.

THIESSEN, D. D., ZOLMAN, J. F., \& RODGERS, D. A. Relation between adrenal weight, brain cholinesterase activity, and hole-in-the-wall behavior under different living conditions. Journal of Comparative \& Physiological Psychology, 1962, 55, 186-190.

THIESSEN, D. D. Population density, mouse genotype, and endocrine function in behavior. Journal of Comparative \& Physiological Psychology, 1964, 57, 412-416.

VANDENBERG, J. G. Eosinophil response to aggressive behavior in CFW mice. Animal Behaviour, 1960, 8, 13-18.

WELCH, B. L., \& KLOPKER, P. H Endocrine variability as a factor in the regulation of population density. American Naturalist, 1961, 95, 256-260. 